УДК 94 (517)

DOI: $10.22162 / 2500-1523-2020-2-216-222$

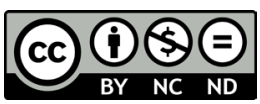

\title{
О Богдо-гэгэне VIII по документам из Центрального архива ФСБ России
}

\author{
Кеемя Владимировна Орлова 1 \\ Федерация) \\ сотрудник \\ (iD) 0000-0003-4951-0063. E-mail: orlovnk@mail.ru \\ (C) КалмНЦ РАН, 2020 \\ (C) Орлова К. В., 2020
}

${ }^{1}$ Институт востоковедения РАН (д. 12, ул. Рождественка, 107031 Москва, Российская

доктор исторических наук, кандидат филологических наук, ведущий научный

\begin{abstract}
Аннотация. Введение. Период 1920-1930-х гг. в истории Монголии до сих пор вызывает наибольшую полемику среди исследователей. Несомненно, эта страница монгольской истории заслуживает пристального внимания, хотя бы в силу неоднозначности происходивших в стране событий - сложных, проблемных и дискуссионных. Именно этот период отражен в сборнике архивных материалов «Монголия в документах из архивов ФСБ России (1922-1936 гг.)». Цель статьи - дать краткий обзор документов из Центрального архива Федеральной службы безопасности РФ, касающихся Джебцзун-Дамба-хутухты Богдо-гэгэна VIII, последнего монгольского хана, в непростой для монголов период — от национально-освободительного движения (1911 г.) до кончины Богдо-гэгэна (1924г.). Maтериальl. Архивные документы включают специальные сообщения, шифрограммы, письма, сводки относительно деятельности Богдо-гэгэна VIII в Монголии. Часть документов относится к предпринятым поискам его перерождения, а также организации ламами движения за реставрацию его власти в стране. Результаты. Выявленные в ЦА ФСБ РФ документы могут служить важным дополнительным источником сведений о деятельности теократического монарха Монголии.
\end{abstract}

Ключевые слова: Монголия, СССР, архив ФСБ РФ, документы, Богдо-гэгэн Для цитирования: Орлова К. В. О Богдо-гэгэне VIII по документам из Центрального архива ФСБ России // Монголоведение. 2020. Т. 12. № 2. С. 216-222. DOI: 10.22162/25001523-2020-2-216-222

\section{Federal Security Service of Russia, Central Archives: $8^{\text {th }}$ Bodg Gegeen Documented}




\section{История}

\section{Keemya V. Orlova ${ }^{1}$}

${ }^{1}$ Institute of Oriental Studies of the RAS (12, Rozhdestvenka St., Moscow 107031, Russian Federation)

Dr. Sc. (History), Cand. Sc. (Philology), Leading Research Associate

(iD)0000-0003-4951-0063. E-mail: orlovnk@mail.ru

(C) KalmSC RAS, 2020

(C) Orlova K. V., 2020

Abstract. Introduction. The 1920s-1930s in Mongolia still give rise to occasional academic debates. And the period does deserve close attention at least due to the ambiguous nature of the then events - complicated, problematic, and largely controversial. The collection of archival materials titled 'Federal Security Service Archives: Mongolia Documented, 1922 1936 ' deals with this very era. Goals. The paper seeks to review documents housed in the Central Archives of Russia's Federal Security Service and relating to the $8^{\text {th }}$ Jebtsundamba Khutuktu (Bogd Gegeen) — the last Khan of Mongolia — in the harsh times between the emergence of the national-liberation movement (1911) and the theocrat's death (1924). Materials. The analyzed official records comprise special messages, coded telegrams, letters, and reports on the $8^{\text {th }}$ Bodg Gegeen's activities in Mongolia. Some documents deal with reincarnation search arrangements and the movement for restoration of theocracy. Results. The discovered files may significantly contribute to the understanding of the theocrat's deeds in Mongolia.

Keywords. Mongolia, USSR, Central Archives of the Federal Security Service of Russia, documents, Bogd Gegeen

For citation: Orlova K. V. Federal Security Service of Russia, Central Archives: $8^{\text {th }}$ Bodg Gegeen Documented. Mongolian Studies (Elista). 2020. Vol. 12. No. 2. Pp. 216-222. (In Russ.) DOI: 10.22162/2500-1523-2020-2-216-222

\section{Введение}

События периода 1920-1930-х гг. в монгольской истории, их сложность и неоднозначность до сих пор вызывают пристальное внимание и наибольшую полемику среди исследователей. Архивные материалы этого периода вошли в сборник «Монголия в документах из архивов ФСБ России (1922-1936 гг.)» [Монголия в документах 2019]. Издание подготовлено монголоведами Отдела Кореи и Монголии Института востоковедения РАН совместно с сотрудниками Центрального архива ФСБ РФ. До недавнего времени документы хранились в архиве под грифами «секретно», «совершенно секретно», многие еще ждут своего открытия.

В сборник вошли 163 документа за 1922-1936 гг., за исключением 1931 г., что связано с засекреченностью материалов. По остальным годам также наблюдается неравномерность открываемых документов, публикация некоторых из них разрешена только в сокращении. Количество опубликованных документов за указанные годы следующее: за 1922 г. — 7, 1923 г. — 21, за 1924 г. - 6, 1925 г. - 22, 1926 г. - 4, 1927 г. - 4, 1928 г. - 29, 1929 г. - 14, 1930 г. - 18, 1932 г. - 3, 1933 г. - 2, $1934-1,1935-25,1936$ г. - 7. Основная тематика архивных материалов посвящена русско/российско-монгольским отношениям, изменениям во внутренней и внешней политике Монголии, произошедшим в 
указанный период, отношениям между РКП(б), Коминтерном и МНРП, политике монгольской партии и правительства относительно религии, борьбе между «правой» и «левой» оппозициями, ряд документов акцентирует внимание на тувинском факторе, большой пласт материалов освещает деятельность полномочных представителей, советников и инструкторов СССР в Монголии и др.

Богдо-гэгэн VIII (1869-1924), глава буддийской церкви Внешней Монголии (время правления 1911-1924)

Часть архивных материалов подробно освещает деятельность Богдо-гэгэна VIII в непростой для монголов период национально-освободительного движения 1911-1912 гг. Родился Богдо-гэгэн в семье тибетского чиновника из администрации Далай-ламы, получил прекрасное образование, степень гавж. В 1874 г. прибыл в Монголию, где постоянным местопребыванием его стал монастырь Их хурэ, в тот же год взошел на престол всемонгольского хана. Линия перерожденцев хутухты связана с одной из влиятельнейших семей Тушету-ханов, потомков чингисидов, начиная с первого Джебцзун-Дамбахутухты - Ундур-гэгэна Дзанабазара. Титул Джебцзун-Дамба-хутухта был дарован Далай-ламой V. После изгнания цинов в 1911 г. «символ национального возрождения» страны [Скрынникова 2015: 186] взошел на престол в декабре того же года, сомкнув на себе и светскую, и духовную власть. По мнению Т. Д. Скрынниковой, «буддизм и глава буддийской церкви Джебцзун-Дамбахутухта становятся действенными идентификационными маркерами общемонгольского единства» [Скрынникова 2015: 188]. Первым указом вновь избранного на ханский престол «живого Будды» было образовано правительство, Урга, переименованная в Нийслэл хурэ, стала столицей нового государства, вместо старого календаря страна перешла на новое летосчисление [История Монголии 2007: 33]. Но не все вопросы решались так же просто: после падения маньчжурской династии претензии китайского республиканского правительства на территорию монголов не утрачивали актуальности. В докладе датского посланника в Пекине Г. Кауфмана по результатам его поездки в Ургу сообщается: «формально Монголия является автономной страной... под китайским суверенитетом, а фактически... Китай не имеет никакого влияния, и китайцы с трудом получают въезд в Монголию» [Монголия в документах 2019: 101]. Противодействие независимости Монголии вызывали многочисленные слухи об обращении Богдо-гэгэна к китайскому правительству вывести русские войска из страны, «ввести китайские войска и создать из Монголии китайскую провинцию» [Монголия в документах 2019: 11, 12]. «Символу возрождения» пришлось выступить со специальным обращением, называя слухи «сплетнями и ложными толками», главную свою задачу он видел в полной поддержке народного правительства и подписании при посредничестве России соглашения между Монголией и Китаем, «которое внесет успокоение и спокойную жизнь обоих народов» [Монголия в документах 2019: 12]. Однако непросто складывались отношения народного правительства с теократическим правителем, в нем видели реальную угрозу преобразованиям в стране. Пытаясь ослабить влияние буддизма (в документе «уничтожить». - K. O.), реализуя курс советского правительства, его советники «всяческим образом пытались притеснять живого Будду», что вызывало бурю негодования монголов. В 1924 г. Богдо- 


\section{История}

гэгэн скончался, но в течение нескольких дней о его кончине не объявляли, опасаясь волнений среди коренного населения. Согласно донесению начальнику Бурято-Монгольского облотдела ОГПУ Ермилову от 30 декабря 1925 г., монголы «горячо желали иметь живого Будду», однако советское правительство всячески препятствовало этому [Монголия в документах 2019: 104].

\section{Поиски перерождения Богдо-гэгэна}

С уходом Богдо-гэгэна VIII в мир иной ограниченная монархия в Монголии перестала существовать, в том же году на I Великом народном хурале была провозглашена Монгольская народная республика, принята первая Конституция. Начался поиск новой реинкарнации Богдо-гэгэна, была создана специальная комиссия. На V съезде МНРП в 1926 г. ученый секретарь Ученого комитета МНР Жамцарано в своем выступлении сообщил, что у одной шаманки ${ }^{1}$ родился мальчик, по всей вероятности, хубилган (перерожденец), однако для точности необходима консультация Далай-ламы XIII, и предложил отправить к нему делегацию [Монголия в документах 2019: 126, 127]. Председатель ЦК МНРП Ц.-О. Дамбадорж на том же заседании съезда в своей речи заявил о недопустимости верить слухам о перерождении Джебцзун-Дамба-хутухты в семье шаманки, эти слухи, по его мнению, «распускают враги, а не друзья» [Монголия в документах 2019: 131]. Позже, в 1928 г., из беседы Жамцарано с сотрудником полпредства СССР в Монголии И. Мининым прояснилась ситуация с сыном шаманки Цэнджав: в ламских кругах его, уже двенадцатилетнего, считали перерождением Богдо-гэгэна (по сведениям И. Минина). На это Ц. Жамцарано уверенно заявил, что он точно не может быть реинкарнацией Богдо, который только три года назад скончался, и предположил, что, скорее всего, этот мальчик - «один из небольших хубилганчиков... из Джеримского сейма Внутренней Монголии, где их очень много... появление перерожденца может быть только с санкции Далай-ламы и Панчен-Богдо» [Монголия в документах 2019: 162]. Через некоторое время тибетский донир (заведующий канцелярией высшего ламы), будучи в Урге, в разговоре с неизвестным лицом высказал свои соображения относительно народного правительства и нового перерождения Богдо-гэгэна. По мнению донира, «если решать пригласить Богдо, надо это сделать организованно и найти надлежащие формы для договора между ламством и светским правительством. Чего может опасаться монгольское правительство, это того, как бы Богдо не захотел узурпировать его власть. Надо заранее установить, чтобы Богдо ведал только делами веры, а правительство - делами светского и государственного характера. Для того чтобы обе стороны могли сговориться, необходимо, чтобы от имени харахунов (мирян) выступил в качестве представителя Полпред СССР, а от имени ламства - Агван Доржиев. Они оба будут своего рода председателями на собрании уполномоченных обеих сторон, которые на этом собрании заключают договор о взаимном разграничении функций и прав для того, чтобы этот договор имел надлежащую форму. Он должен быть письменно зафиксирован и скреплен печатями, в том числе и пе-

\footnotetext{
${ }^{1}$ Имелась в виду женщина Цэнджав, которую еще называли Мэргэн хуухэн, у нее в 1925 г. родился сын, и его, по слухам, считали перерождением Богдо-гэгэна. Однако этот факт не получил канонического подтверждения, а сам процесс выявления не был доведен до конца [Кузьмин 2016: 384].
} 
чатью Далай-ламы, который тем самым поручится за непревышение власти будущим Богдо. В случае превышения власти Далай-лама отзовет Богдо-гэгэна. Ручательство Далай-ламы - достаточная гарантия хотя бы даже из того, что в противном случае получится международный скандал. Сам же Богдо, ежели он будет приглашен, вовсе не должен жить здесь с самого начала. Вольное поведение покойного Богдо очень подорвало авторитет духовной власти. Надо, чтобы будущий Богдо был в Тибете под строгой дисциплиною, замкнуто, в обществе не более пяти человек (повар, чаечерпий, лакей, завхоз и учитель), должен периодически являться к Далай-ламе, который будет его экзаменовать. Когда он сделается большим ученым, он должен приехать сюда, жить в Дзун-хурэ очень строгой жизнью, причем должен быть строгий учитель-представитель Далайламы для надзора, постоянного оказания давления на него и для отзыва его в Тибет в случае неподобающего поведения. Он должен вести жизнь ученика, никуда не отлучаться по собственному желанию и лишен женщин. Миряне к нему должны допускаться для поклонения в строго определенные дни месяца, вне которых он ни с кем из них не может видеться. Он ведает всеми духовными делами и только. Такого Богдо-гэгэна монгольскому правительству бояться нечего» [Монголия в документах 2019: 164].

Однако решением V Великого народного хурала МНР (1928-1929 гг.) поиски нового Богдо были прекращены [Батсайхан 2018: 356, 361]. Среди верующего населения и высшего ламства поиск не прекращался, как не прерывалось и движение за «реставрацию власти Богдо-гэгэна» [Монголия в документах 2019: 167]. В 1928 г. в информационном сообщении из УланБатора отмечалось: «в последнее время особенно много стало нарождаться детей, имевших признаки на перерождение Богдо... наши монголы с нетерпением ждут выяснение вопроса о перерождении и даже члены правительства... являются активными сторонниками восстановления власти Богдо». К этому вопросу подключился и Агван Доржиев во время пребывания в Улан-Баторе, его принципиальная позиция заключалась в том, чтобы «признанный перерожденец-мальчик не воспитывался в развращенной и отрицательной среде... Если новоявленный Богдо будет воспитываться в Тибете, в строгой моральной обстановке около Далай-ламы, тогда можно ожидать, что такой Богдо будет действительно полезен для религии» [Монголия в документах 2019: 168, 172]. В начале октября 1928 г. вышло специальное постановление Духовного управления, в котором было сказано о необходимости «прекратить ложные слухи и домыслы ...о нахождении и приглашении перерожденца, ...письменные разъяснения разослать всем аймакам, цогчинам, дацанам и дворцам» [Монголия в документах 2019: 175]. В информационном сообщении Восточного отдела Объединенного государственного политического управления (1929 г.) говорилось о возможном приезде Панчена-ламы в Даригангу (Шилингийский сейм Внутренней Монголии), о ламстве, рассчитывающем восстановить в Монголии власть Богдо. В связи с этим предлагалось закрыть границу для паломников [Монголия в документах 2019: 186]. Но и высшее ламство не теряло времени даром: был организован выпуск листовок с изображением Панчен-ламы и сообщением о том, что он «должен явиться в Монголию в образе главнокомандующего и ...избавить страну от 


\section{История}

красных». В народе пошла молва, что при Панчене находится перерожденец Богдо-гэгэна VIII. Это был, как считали сами ламы, «пробный шар... нащупать настроения правительственных кругов... поколебать неустойчивые ряды партии» [Монголия в документах 2019: 242, 243]. Одновременно ламы УланБатора всячески препятствовали светскому образованию, увеличивали сборы и подношения в пользу храмов, тайно организовывая на территории страны «опорные базы» в качестве «убежищ для всяких контрреволюционных беглецов... хутухт внутри страны, ламства Бурятии, Внутренней Монголии и Тибета» [Монголия в документах 2019: 243, 251]. Но и народное правительство предпринимало соответствующие шаги: проводилась работа по расслоению ламства на «враждующие группы», особенно среди иерархов, стимулированию перехода низших лам в светское состояние, лишению хутухт и хубилганов права распоряжаться джасамиㄹ․ Основной упор правительства был направлен на перевод лам в светское состояние. В таблице 1 приводятся данные о численности лам за 1930 г. по шести аймакам Монголии:

Таблица 1. Приблизительные сведения о количестве лам, перешедших в черное состояние ${ }^{3}$ по пяти ${ }^{4}$ аймакам МНР за 1930 г.

[Table 1. Approximate numbers of Buddhist priests converted to commoners across five (six) provinces of the Mongolian People's Republic in 1930]

\begin{tabular}{|c|c|c|c|c|c|}
\hline $\begin{array}{l}\text { № } \\
\Pi / \Pi\end{array}$ & $\begin{array}{c}\text { Наименование } \\
\text { аймаков }\end{array}$ & $\begin{array}{c}\text { Число пе- } \\
\text { реведенных } \\
\text { в хара }\end{array}$ & $\begin{array}{c}\text { Сколько из } \\
\text { них получали } \\
\text { хуби }^{5}\end{array}$ & $\begin{array}{c}\text { Размер } \\
\text { хуби }\end{array}$ & Примечания \\
\hline 1 & $\begin{array}{l}\text { Богдо-хан- } \\
\text { ульск[ий] }\end{array}$ & 558 & - & - & $\begin{array}{l}\text { С начала джаской кампании } \\
15 \text { сентября [1930 г.] }\end{array}$ \\
\hline 2 & $\begin{array}{l}\text { Хан-Хэнтей- } \\
\text { ульск[ий] }\end{array}$ & 2588 & - & - & На 15 сентября [19]30 г. \\
\hline 3 & $\begin{array}{l}\text { Цэцэрлэг- } \\
\text { Мандал }\end{array}$ & 920 & 80 & 820 & $\begin{array}{l}\text { Сведения о хуби только по Хан- } \\
\text { Хугшин хошуну и на } 15 \text { августа } \\
{[19] 30 \text { г. }}\end{array}$ \\
\hline 4 & Хан-Тайшир & 1046 & - & - & На 4 сентября [19]30 г. \\
\hline 5 & $\begin{array}{l}\text { Чандмань- } \\
\text { ульск[ий] }\end{array}$ & 1339 & - & - & $\begin{array}{l}\text { На } 1 \text { июня [19]30 г. Упразднено } \\
\text { монастырей } 6\end{array}$ \\
\hline 6 & $\begin{array}{l}\text { Улан-Батор } \\
\text { ([монастыри] } \\
\text { Гандан, Дзун- } \\
\text { хурэн) }\end{array}$ & 529 & 414 & $\begin{array}{c}271881 \\
540 \text { т. }^{6}\end{array}$ & На 15 августа [19]30 г. \\
\hline
\end{tabular}

Итого: 6 9527 [Монголия в документах 2019: 334].

В комментарии к таблице даются пояснения об условности («ориентировочности») приведенных цифр в связи с использованием административного pecypca.

В результате противостояние народного правительства и буддийского духовенства вылилось в восстания в Западной Монголии (1930 г.), на Хубсугуле

\footnotetext{
2 Джаса - с середины XVII в. накопления и хозяйство монашеской общины буддийской церкви Монголии.

${ }^{3}$ Перейти в черное (хара) состояние - в светское состояние.

${ }^{4}$ В заголовке документа ошибочно указаны пять аймаков, данные приведены по шести аймакам

${ }^{5}$ Хуби - доля, пай, условная счетная налоговая единица.

${ }^{6}$ Так в документе. Вероятно, сокращение от «тугрики».

7 Общее количество перешедших в светское состояние подсчитано некорректно, должно быть 6980.
} 
(1932 г.). Дальнейшие события в Монголии привели к уничтожению духовенства и прерыванию буддийской традиции.

\section{Заключение}

Богдо-гэгэн VIII в годы своего правления (1911-1924), как высший духовный иерарх и светский правитель Монголии, в силу сложившихся обстоятельств стал объединяющим духовным и общенациональным лидером. И только с ним монголы связывали возрождение и развитие своей страны.

\section{Литература}

Батсайхан 2018 - Батсайхан О. Последний великий хан Монголии Богдо Джебцзундамба-хутухта VIII. Жизнь и легенды. М.: Товарищество научных изданий КМК, 2018. 406 с.

История Монголии 2007 - История Монголии. ХХ век / отв. ред. Г. С. Яскина. М.: ИВ PAH, 2007. $448 \mathrm{c}$.

Монголия в документах 2019 - Монголия в документах из архивов ФСБ России (19221936 гг.) / науч. ред. В. В. Наумкин, отв. ред. К. В. Орлова, В. В. Грайворонский. М.: ИВ РАН, 2019. $528 \mathrm{c.}$

Кузьмин $2016-$ Кузьмин С. Л. Теократическая государственность и буддийская церковь в Монголии в начале XX в. М.: Товарищество научных изданий КМК, 2016. $496 \mathrm{c}$.

Скрынникова 2015 - Скрынникова Т. Д. Роль буддийской церкви в Монголии первой четверти ХХ в. // «Я рад, что стал монголоведом». К 85-летию С. К. Рощина. М.; Улан-Батор: ИВ РАН, Ин-т истории и археологии АН Монголии, 2015. С. 177-190.

\section{References}

Batsaykhan O. $8^{\text {th }}$ Bogd Jebtsundamba Khutuktu - Last Khan of Mongolia: Life and Legends. Moscow: KMK, 2018. 406 p. (In Russ.)

Kuzmin S. L. Mongolia in the Early $20^{\text {th }}$ Century: Theocratic State and Buddhist Church. Moscow: KMK, 2016. 496 p. (In Russ.)

Naumkin V. V. et al. (eds.) Federal Security Service Archives: Mongolia Documented, 19221936. Moscow: Institute of Oriental Studies (RAS), 2019. 528 p. (In Russ.)

Skrynnikova T. D. Mongolia, 1900s-1920s: role of Buddhist church. In: 'I Am Glad to Have Become a Mongolist': Celebrating the $85^{\text {th }}$ Birthday of Prof. S. Roshchin. Moscow Ulaanbaatar: Institute of Oriental Studies (RAS), Institute of History and Archaeology (Mongolian Academy of Sciences), 2015. Pp. 177-190. (In Russ.)

Yaskina G. S. (ed.) History of Mongolia: $20^{\text {th }}$ Century. Moscow: Institute of Oriental Studies (RAS), 2007. 448 p. (In Russ.) 